\title{
Brain immune cell composition and functional outcome after cerebral ischemia: comparison of two mouse strains
}

\author{
Hyun Ah Kim ${ }^{1}$, Stephanie C. Whittle ${ }^{1}$, Seyoung Lee ${ }^{1}$, Hannah X. Chu ${ }^{1}$, Shenpeng R. Zhang ${ }^{1}$, \\ Zihui Wei ${ }^{1}$, Thiruma V. Arumugam ${ }^{2,3,4}$, Anthony Vinh ${ }^{1}$, Grant R. Drummond ${ }^{1,5}$ and \\ Christopher G. Sobey ${ }^{1,5}$ *
}

${ }^{1}$ Department of Pharmacology, Monash University, Clayton, VIC, Australia

2 Department of Physiology, Yong Loo Lin School of Medicine, National University of Singapore, Singapore, Singapore

${ }^{3}$ School of Pharmacy, Sungkyunkwan University, Suwon, South Korea

${ }^{4}$ School of Biomedical Sciences, The University of Queensland, St Lucia, QLD, Australia

${ }^{5}$ Department of Surgery, Monash Medical Centre, Southern Clinical School, Monash University, Clayton, VIC, Australia

Edited by:

Christoph Kleinschnitz, University of Würzburg, Germany

Reviewed by:

Christoph Kleinschnitz, University of Würzburg, Germany

Prasad V. Katakam, Tulane

University School of Medicine, USA

*Correspondence:

Christopher G. Sobey, Department

of Pharmacology, Monash

University, Wellington Road,

Clayton, VIC 3800, Australia

e-mail: chris.sobey@monash.edu
Inflammatory cells may contribute to secondary brain injury following cerebral ischemia. The C57BI/6 mouse strain is known to exhibit a $\mathrm{T}$ helper 1-prone, pro-inflammatory type response to injury, whereas the FVB strain is relatively $T$ helper 2-prone, or anti-inflammatory, in its immune response. We tested whether stroke outcome is more severe in $\mathrm{C} 57 \mathrm{BI} / 6$ than FVB mice. Male mice of each strain underwent sham surgery or $1 \mathrm{~h}$ occlusion of the middle cerebral artery followed by $23 \mathrm{~h}$ of reperfusion. Despite no difference in infarct size, C57BI/6 mice displayed markedly greater functional deficits than FVB mice after stroke, as assessed by neurological scoring and hanging wire test. Total numbers of $\mathrm{CD}_{4} 5^{+}$leukocytes tended to be larger in the brains of $\mathrm{C} 57 \mathrm{BI} / 6$ than FVB mice after stroke, but there were marked differences in leukocyte composition between the two mouse strains. The inflammatory response in C57BI/6 mice primarily involved T and B lymphocytes, whereas neutrophils, monocytes and macrophages were more prominent in FVB mice. Our data are consistent with the concept that functional outcome after stroke is dependent on the immune cell composition which develops following ischemic brain injury.

Keywords: cerebral ischemia-reperfusion, immune cell infiltration, inflammation, middle cerebral artery occlusion, stroke, Th1/Th2 balance

\section{INTRODUCTION}

Stroke is the 4th leading cause of death after heart disease, cancer and chronic lower respiratory disease, and over a third of survivors are left with major neurological injury (Go et al., 2013). Approximately $85 \%$ of stroke cases are of the ischemic type (Go et al., 2013), in which an embolus or local thrombus causes occlusion of a major cerebral artery and results in disruption of brain blood flow. Whilst thrombolysis by intravenous recombinant tissue plasminogen activator (rt-PA) may be effective in improving outcome by promoting reperfusion, it has a number of limitations, including a short therapeutic window of $3-4.5 \mathrm{~h}(<10 \%$ of stroke patients receive rt-PA) (Gravanis and Tsirka, 2008). For further advances in the clinical treatment of ischemic stroke, the complex mechanisms of cellular injury following cerebral ischemia must be elucidated to provide novel targets for future therapies.

It is now established that the initial insult in ischemic stroke is followed by induction of cytokines and chemokines, which attract numerous inflammatory cell types to the damaged brain region, which ultimately contribute to secondary brain injury (Gelderblom et al., 2009; Chu et al., 2014). Growing evidence indicates the importance of $\mathrm{T}$ lymphocytes in cerebral ischemic damage, whereby they become activated and infiltrate the brain within $24 \mathrm{~h}$ (Yilmaz et al., 2006; Hurn et al., 2007; Urra et al., 2009a), although the mechanism(s) underlying their actions are not fully clear. Recombination activating gene 1-deficient mice, which lack $\mathrm{T}$ and $\mathrm{B}$ lymphocytes, have less severe brain injury following cerebral ischemia, and this protection is lost upon reconstitution with $\mathrm{T}$ but not B lymphocytes (Yilmaz et al., 2006; Kleinschnitz et al., 2010).

T lymphocytes $\left(\mathrm{CD}^{+}\right.$cells) are mostly comprised of $\mathrm{CD} 4^{+}$ $\mathrm{T}$ helper (Th) and $\mathrm{CD}^{+}{ }^{+}$cytotoxic $\mathrm{T}(\mathrm{Tc})$ cell subpopulations, both of which are thought to play detrimental roles in ischemic stroke (Yilmaz et al., 2006). There is also evidence that regulatory $\mathrm{T}$ lymphocytes (Tregs; $\mathrm{CD} 4^{+} \mathrm{CD} 25^{+} \mathrm{FoxP}^{+}$) may modulate the severity of stroke outcome (Liesz et al., 2009), despite exerting acutely detrimental effects by promoting intravascular coagulation during reperfusion (Kleinschnitz et al., 2013). Major distinct Th cell types include Th1 and Th2, and are defined according to the cytokines they release (Abbas et al., 1996). In general terms, Th1 cells promote an inflammatory response through secretion of pro-inflammatory cytokines [e.g., interleukin(IL)2 , IL-12, interferon(IFN)- $\gamma$, and tumor necrosis factor(TNF)- $\alpha$ ], whereas Th2 cells promote a humoral or allergic response by 
secretion of anti-inflammatory cytokines (e.g., IL-4, IL-10, and IL-13) (Arumugam et al., 2005; Jin et al., 2010).

Clarification of the importance of Th1 and Th2 immunity in acute stroke is needed to define the complex evolution of cerebral ischemic injury and potentially identify therapeutic strategies to limit stroke injury. Here, we have studied representative mouse strains commonly accepted as Th1-dominant (C57Bl/6) and Th2-dominant (FVB) (Whitehead et al., 2003) to investigate stroke outcome in a prototypical Th1- or Th2-prone immune environment, respectively.

\section{MATERIALS AND METHODS ANIMALS}

This study fully adheres to the Animal Research: Reporting In Vivo Experiments (ARRIVE) guidelines (Kilkenny et al., 2010). All animal experiments were conducted in accordance with National Health and Medical Research Council of Australia guidelines for the care and use of animals in research and approved by the Monash University Animal Ethics Committee (Projects SOBSB/2010/10 and SOBSB/2011/112). A total of 201 male mice (C57Bl/6: $n=89,19-33 \mathrm{~g}$; FVB: $n=112,25-39 \mathrm{~g})$ aged $8-15$ weeks were studied. The mice had free access to water and food pellets before and after surgery. Thirty-seven mice were excluded from the study because they: (1) died during surgical procedure (C57Bl/6: $n=12$; FVB: $n=24$ ) or (2) were euthanized prior to $24 \mathrm{~h}$ as per institutional ethics requirements due to severe functional impairment (C57Bl/6: $n=1)$.

\section{TRANSIENT FOCAL CEREBRAL ISCHEMIA}

Focal cerebral ischemia was induced by transient intraluminal filament occlusion of the right middle cerebral artery (MCA) as described previously (Jackman et al., 2009; Brait et al., 2010). Mice were anesthetized with ketamine-xylazine $(80$ and $10 \mathrm{mg} / \mathrm{kg}$, respectively; intraperitoneal). Rectal temperature was monitored and maintained at $37.5 \pm 0.5^{\circ} \mathrm{C}$ throughout the procedure and until animals regained consciousness using an electronic temperature controller (Testronics, Kinglake, Victoria, Australia) linked to a heat lamp. The right proximal common carotid artery was clamped, and a 6-0 nylon monofilament with silicone-coated tip (Doccol Co., Redlands, CA, USA) was inserted and gently advanced into the distal internal carotid artery, $11-12 \mathrm{~mm}$ distal to the carotid bifurcation, occluding the MCA at the junction of the Circle of Willis. Severe $(\sim 80 \%)$ reduction in regional cerebral blood flow (rCBF) was confirmed using transcranial laser-Doppler flowmetry (Perimed, Järfälla, Sweden) in the area of cerebral cortex supplied by the MCA. The filament was then tied in place and the clamp was removed. After $1 \mathrm{~h}$ of cerebral ischemia, the monofilament was retracted to allow reperfusion for $23 \mathrm{~h}$. Reperfusion was confirmed by an immediate increase in $\mathrm{rCBF}$, which reached the pre-ischemic level within $5 \mathrm{~min}$. The wound was then closed and the animal was allowed to recover. Regional CBF was recorded for $30 \mathrm{~min}$ after the induction of reperfusion. Sham-operated mice were anesthetized and the right carotid bifurcation was exposed, dissected free from surrounding connective tissue but no filament was inserted. All animals were administered $1 \mathrm{~mL}$ of sterile saline via a subcutaneous injection for rehydration after surgery.

\section{NEUROLOGICAL ASSESSMENT}

At the end of the experiment ( $24 \mathrm{~h}$ after induction of stroke/sham surgery), neurological assessment was performed using a modified six-point scoring system (Jackman et al., 2009; Brait et al., 2010): 0 , normal motor function; 1 , flexion of torso and contralateral forelimb when mouse is lifted by the tail; 2 , circling when mouse held by the tail on a flat surface; 3 , leaning to the one side at rest; 4 , no spontaneous motor activity; 5 , death within $24 \mathrm{~h}$. A hanging wire test was also performed in which mice were suspended from a wire $30 \mathrm{~cm}$ high for up to $180 \mathrm{~s}$, and the average time of 3 trials with 5-min rest periods in between was recorded. Neurological assessment was evaluated by an observer blinded to experimental groups.

\section{CEREBRAL INFARCT AND EDEMA VOLUMES}

Mice were killed at $24 \mathrm{~h}$ by inhalation of isoflurane, followed by decapitation. The brains were immediately removed and snap frozen with liquid nitrogen. Coronal sections $(30 \mu \mathrm{m})$ separated by $\sim 420 \mu \mathrm{m}$ were obtained and stained with thionin $(0.1 \%)$ to delineate the infarct. Images of the sections were captured with a CCD camera mounted above a light box. Infarct volume was quantified as described previously (Jackman et al., 2009; Kim et al., 2012) using image analysis software (ImageJ, NIH, Bethesda, MD, USA), and corrected for brain edema, estimated using the following formula: corrected infarct volume $=$ [left hemisphere area - (right hemisphere area - right hemisphere infarct area $) \times($ thickness of section + distance between sections)] (Tsuchiya et al., 2003; Xia et al., 2006). Edema-corrected infarct volumes of individual brain sections were then added giving a three-dimensional approximation of the total infarct volume. Total, cortical and subcortical infarct volumes were quantified individually.

\section{GROSS CEREBROVASCULAR ANATOMY}

For gross comparison of cerebrovascular anatomy, some naïve animals ( $n=3$ of each strain, without any surgical procedures) were deeply anesthetized by inhalation of isoflurane, the thorax was opened and intracardial perfusion was performed with PBS, followed by $4 \%$ paraformaldehyde and finally $4 \%$ Evans blue solution in $20 \%$ gelatin.

\section{FLOW CYTOMETRY}

On each occasion when flow cytometry was utilized, we studied at least one post-stroke mouse together with a time-matched sham-operated control mouse of each strain. Animals were euthanized at $24 \mathrm{~h}$ by inhalation of isoflurane, followed by blood removal by cardiac puncture and the whole mouse was then intracardially perfused with phosphate-buffered saline (PBS) and brain, blood, and spleen were collected. Leukocytes were purified from blood using red blood cell lysis buffer $(155 \mathrm{mmol} / \mathrm{L}$ $\mathrm{NH}_{4} \mathrm{Cl}, 10 \mathrm{mmol} / \mathrm{L} \mathrm{KHCO}_{3}$, and $3 \mathrm{mmol} / \mathrm{L}$ EDTA). Spleens were mechanically dissociated and passed through $70 \mu \mathrm{m}$ nylon cell strainers (BD Falcon, Bedford, MA, USA) to obtain a single-cell suspension. Cells were then lysed with red blood cell lysis buffer and washed with PBS containing $1 \%$ bovine serum albumin. The brain was removed from the skull and after removing the cerebellum and olfactory bulb, was separated into left (contralateral) and 
right (ischemic) hemispheres. Each hemisphere was dissociated mechanically in digestion buffer containing collagenase type XI $(125 \mathrm{U} / \mathrm{mL})$, hyaluronidase $(60 \mathrm{U} / \mathrm{mL})$, and collagenase type I-S $(450 \mathrm{U} / \mathrm{mL})$ in $\mathrm{Ca} 2^{+} / \mathrm{Mg}^{+}{ }^{+}$-supplemented PBS (Sigma, St Louis, $\mathrm{MO}, \mathrm{USA}$ ), and incubated at $37^{\circ} \mathrm{C}$ for $30 \mathrm{~min}$ with gentle agitation. The mixture was then passed through $70 \mu \mathrm{m}$ nylon cell strainers to obtain a single-cell suspension. After washing with PBS (1200 rpm, $10 \mathrm{~min}$ ), the cell pellet was resuspended in $3 \mathrm{~mL}$ $30 \%$ percoll (GE Healthcare, Uppsala, Sweden), underlaid with $70 \%$ percoll, and centrifuged for $20 \mathrm{~min}$ at $2400 \mathrm{rpm}$ at room temperature without the use of a brake. The cells at the interphase of two density gradients were collected and washed with PBS containing 1\% bovine serum albumin (1200 rpm, $10 \mathrm{~min}$ ) for staining. All cells were incubated with appropriate antibodies listed in Table 1 at $4^{\circ} \mathrm{C}$ in darkness for $20 \mathrm{~min}$. After staining, cells were analyzed by LSRII flow cytometer (BD Biosciences, Franklin Lakes, NJ, USA) and FlowJo software (Tree Star Inc., Ashland, OR, USA). Countbright counting beads (Invitrogen, Carlsbad, CA, USA) were included to define the absolute number of cells in the samples.

\section{GATING STRATEGY}

Single cells were identified by forward scatter, and dead cells (7-amino actinomycin $\mathrm{D}^{+}$) were excluded. Cells were gated for $\mathrm{CD} 45^{\text {thigh }}$ and $\mathrm{CD} 45^{\text {med }}$ populations as described previously (Chu et al., 2014). CD45 thigh populations were then divided into lymphoid cells, which include: $\mathrm{B}$ cells $\left(\mathrm{B} 220^{+}\right), \quad \mathrm{T}$ cells $\left(\mathrm{CD} 49 \mathrm{~b}^{+} \mathrm{CD}^{-} 0^{-} \mathrm{NK} 1.1^{-}\right)$, thymocytes $\left(\mathrm{CD} 49 \mathrm{~b}^{-} \mathrm{CD}^{+} 0^{+} \mathrm{NK} 1.1^{-}\right)$, NK cells $\left(\mathrm{CD} 49 \mathrm{~b}^{+} \mathrm{CD} 90^{+} \mathrm{NK} 1.1^{+}\right)$, and $\mathrm{NKT}$ cells $\left(\mathrm{CD} 49 \mathrm{~b}^{+} \mathrm{CD} 90^{-} \mathrm{NK} 1.1^{+}\right)$; and myeloid cells $\left(\mathrm{CD} 11 \mathrm{~b}^{+}\right) . \mathrm{CD} 5^{+ \text {med }} \mathrm{CD} 11 \mathrm{~b}^{+} \mathrm{F} 4 / 80^{+}$cells were considered microglia. Two panels of antibodies were used, one of which was employed with each animal. Panel 1 enabled the counting of microglia and myeloid-derived leukocytes (i.e., $\mathrm{CD}_{11 \mathrm{~b}^{+}}$ cells), which include: neutrophils $\left(\mathrm{Ly} 6 \mathrm{G}^{+}\right)$, monocytes $\left(\mathrm{Ly}_{6} \mathrm{C}^{+}\right)$, macrophages $\left(\mathrm{F} 4 / 80^{+}\right)$, and dendritic cells $\left(\mathrm{CD} 11 \mathrm{c}^{+}\right)$; whereas

Table 1 | Summary of antibodies used for flow cytometry.

\begin{tabular}{lll}
\hline Antigen & Host/lsotype & Supplier \\
\hline CD8a-APC & Rat IgG2a, kappa & BD Phamingen \\
CD19-PE & Rat IgG2a, kappa & BioLegend \\
CD11c-Brilliant Violet 570 & ArHam IgG & BioLegend \\
CD25-PE-Cy7 & Rat IgG1, lambda & BioLegend \\
CD4-FITC & Rat IgG2b, kappa & BioLegend \\
CD45-APC-Cy7 & Rat IgG2b, kappa & BioLegend \\
CD49b-PE & ArHam IgG & BioLegend \\
CD90.2-PE & Rat IgG2b, kappa & BioLegend \\
Ly6C-FITC & Rat IgG2c, kappa & BioLegend \\
Ly6G-PE-Cy7 & Rat IgG2a, kappa & BioLegend \\
NK1.1-PE & Mouse IgG2a, kappa & BioLegend \\
CD11b-eFluro450 & Rat IgG2b, kappa & eBioscience \\
CD3-eFluro450 & Rat IgG2b, kappa & eBioscience \\
F4/80-APC & Rat IgG2a, kappa & eBioscience \\
7-Amino-actinomycin D & & Invitrogen \\
(7AAD) & &
\end{tabular}

Panel 2 divided lymphocytes into: B cells $\left(\mathrm{CD} 19^{+}\right)$and $\mathrm{T}$ cells $\left(\mathrm{CD}^{+}\right)$. T cells were then further subdivided into $\mathrm{CD} 4^{+} \mathrm{T}$ cells, $\mathrm{CD}^{+} \mathrm{T}$ cells, $\mathrm{CD} 4^{-} \mathrm{CD} 8^{-} \mathrm{T}$ cells, and $\mathrm{CD} 4^{+} \mathrm{CD} 25^{+} \mathrm{T}$ cells. Fluorescence-minus-one were included as negative controls to define positive populations for F4/80, CD11c, Ly6C, CD19, CD3, and CD25.

\section{CYTOKINE MEASUREMENT}

Single-cell suspensions of brain, blood and spleen were obtained as described for flow cytometry. All cells were resuspended in complete RPMI 1640 media supplemented with heat inactivated fetal bovine serum $(10 \% \mathrm{w} / \mathrm{v})$, streptomycin and penicillin (100 U/mL), L-glutamine (1\%) and 2-mercaptoethanol (50 mM). Blood and spleen cells were seeded at 200,000 cells/well in a 96well plate coated with anti-CD3. All cells in the brain hemisphere were seeded. Blood, spleen, and contralateral brain hemisphere of sham-operated mice was seeded as unstimulated controls. Recombinant mouse IL-2 $(20 \mathrm{ng} / \mathrm{mL})$ was added and cells were incubated for $48 \mathrm{~h}$ at $37^{\circ} \mathrm{C}$ in a humidified atmosphere of $5 \%$ $\mathrm{CO}_{2}$ in air. After stimulation, cells were spun down $(15,000 \mathrm{rpm}$, $5 \mathrm{~min}$ ) and supernatant was collected. Samples were analyzed for 7 key inflammatory cytokines (IL-4, IL-6, IL-10, IL-17A, IFN- $\gamma$, and TNF- $\alpha$ ) using Cytometric Bead Array Mouse Th1/Th2/Th17 Cytokine kit (BD Biosciences, Franklin Lakes, NJ, USA). Samples and standards were prepared according to manufacturer's protocol. After adding capture beads, cells were analyzed by LSRII flow cytometer (BD Biosciences, Franklin Lakes, NJ, USA) and FCAP Array software (BD Biosciences, Franklin Lakes, NJ, USA).

\section{STATISTICAL ANALYSIS}

Values are presented as mean \pm standard error. Results of the hanging wire test, infarct volume and flow cytometry, comparing $\mathrm{C} 57 \mathrm{Bl} / 6$ and FVB sham- or stroke-operated mice, were analyzed using one-way analysis of variance with Bonferroni post-hoc test with selected multiple comparisons or a Student's unpaired $t$-test, as appropriate. The neurological deficit score was expressed as the median result per group and was analyzed using a Kruskal-Wallis test with Dunn's post-hoc test. A $P$ value $<0.05$ was considered statistically significant. Statistical analyses were carried out using GraphPad Prism (GraphPad Software Inc, La Jolla, CA, USA).

\section{RESULTS \\ CEREBRAL BLOOD FLOW PROFILE AND MORTALITY}

CBF was similarly reduced by $\sim 80 \%$ in both $\mathrm{C} 57 \mathrm{Bl} / 6$ and FVB mice following insertion of the monofilament (Figure 1A). No significant differences in CBF profiles were observed between $\mathrm{C} 57 \mathrm{Bl} / 6$ and $\mathrm{FVB}$ mice. Mortality rates at $24 \mathrm{~h}$ after cerebral ischemia were $8.8 \%(3 / 34)$ and $2.9 \%(1 / 34)$ in $\mathrm{C} 57 \mathrm{Bl} / 6$ and $\mathrm{FVB}$ mice, respectively (Figure 1B). Mice of both strains had no significant differences in the cerebrovascular anatomy; in particular, the posterior communicating arteries were present in both strains (Supplementary Figure 1).

\section{NEUROLOGICAL FUNCTION}

Mice of both strains typically had no neurological deficit (score of 0 ) at $24 \mathrm{~h}$ after sham surgery (Figure 1B). Following cerebral ischemia, both $\mathrm{C} 57 \mathrm{Bl} / 6$ and FVB mice had significant 

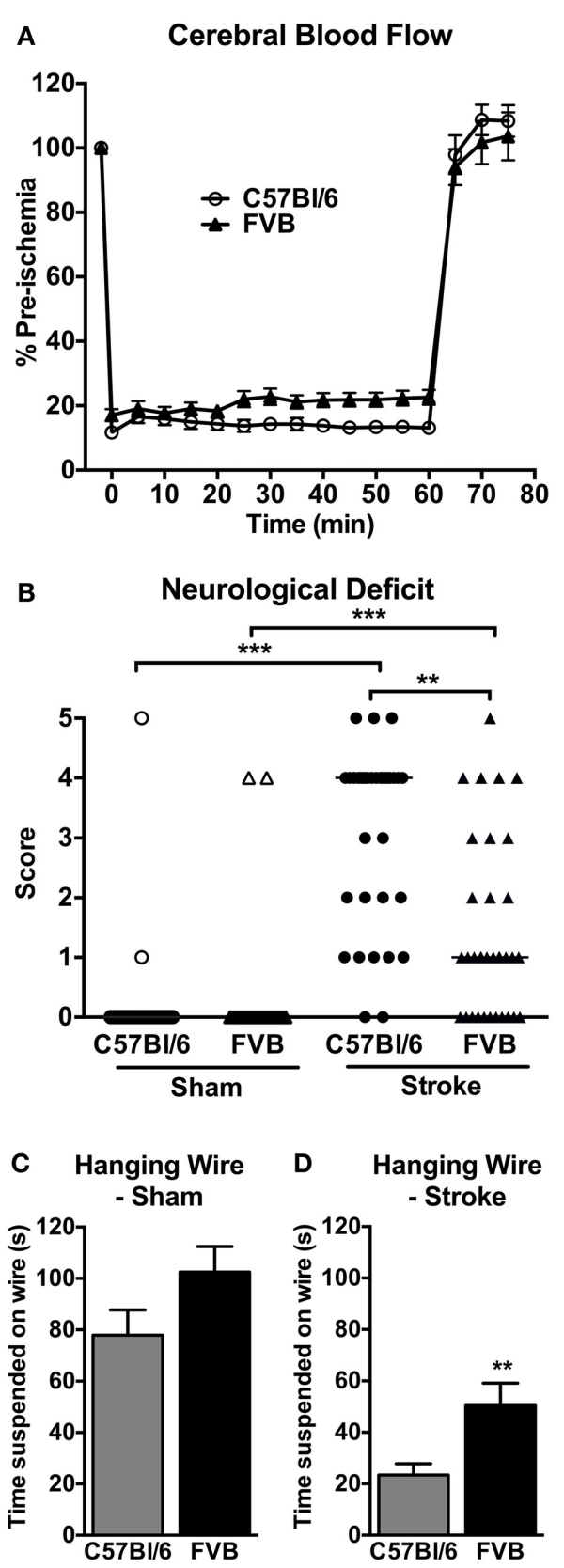

FIGURE 1 | (A) Regional cerebral blood flow during $1 \mathrm{~h}$ middle cerebral artery occlusion ( $n=30-31$ ); (B) neurological deficit ( $n=29-34$;

${ }^{* *} P<0.01$, ${ }^{* * *} P<0.001$; Kruskal-Wallis with Dunn's post-tests) and (C,D) hanging wire performance $\left(n=28-33 ;{ }^{* *} P<0.01\right.$; Student's unpaired $t$-test) at $24 \mathrm{~h}$ after cerebral ischemia. There was less functional impairment in FVB mice compared to C57BI/6 mice. Data are mean \pm s.e.m. in $\mathbf{( A , C , D )}$, and are median scores in (B)

neurological deficit compared to sham-operated mice of the same strain, although $\mathrm{C} 57 \mathrm{Bl} / 6$ mice had greater deficit than FVB mice. Similarly, in the hanging wire test sham-operated $\mathrm{C} 57 \mathrm{Bl} / 6$ and FVB mice achieved comparable hanging times (Figure 1C), whereas FVB mice achieved $\sim 2$-fold longer hanging times than $\mathrm{C} 57 \mathrm{Bl} / 6$ mice at $24 \mathrm{~h}$ following cerebral ischemia (Figure 1D).

\section{INFARCT AND EDEMA VOLUMES}

Representative coronal sections of $\mathrm{C} 57 \mathrm{Bl} / 6$ and $\mathrm{FVB}$ brains at $24 \mathrm{~h}$ after MCA occlusion are shown in Figures 2A,B, respectively. $\mathrm{C} 57 \mathrm{Bl} / 6$ and $\mathrm{FVB}$ mice had similar total infarct (Figure 2C), cortical infarct (Figure 2E), subcortical infarct (Figure 2F) and edema (Figure 2D) volumes.

\section{LEUKOCYTE INFILTRATION IN THE BRAIN}

There was a $\sim 4$-fold increase in the total number of leukocytes in the ischemic hemisphere of $\mathrm{C} 57 \mathrm{Bl} / 6$ mice compared to sham-operated mice $(P<0.01$, Figure 3A). There also tended to be an increase in total leukocytes following ischemia in FVB mice, but there were $\sim 40 \%$ fewer leukocytes than in $\mathrm{C} 57 \mathrm{Bl} / 6$ mice (Figure 3A). Myeloid cells $\left(\mathrm{CD} 11 \mathrm{~b}^{+}\right)$, comprising neutrophils $\left(\mathrm{Ly}_{6 \mathrm{G}}{ }^{+}\right)$, dendritic cells $\left(\mathrm{CD} 11 \mathrm{~b}^{+} \mathrm{CD} 11 \mathrm{c}^{+}\right)$, macrophages $\left(\mathrm{F} 4 / 80^{+}\right)$and monocytes $\left(\mathrm{Ly}_{6} \mathrm{C}^{+}\right)$, were increased by a $\sim 15$-fold in the ischemic hemisphere of FVB mice to levels that were twice those in $\mathrm{C} 57 \mathrm{Bl} / 6$ mice $(P<0.01$, Figure $3 \mathrm{~B})$. By contrast, lymphoid cells were increased by $2-3$-fold following ischemia in $\mathrm{C} 57 \mathrm{Bl} / 6$ mice, whereas there was no change in lymphoid cell numbers in the brains of FVB mice following stroke (Figure 3C). No significant effect of stroke was observed in the number of microglia $\left(\mathrm{CD} 45^{+ \text {med }} \mathrm{CD} 11 \mathrm{~b}^{+} \mathrm{F} 4 / 80^{+}\right)$in either strain (Figure 3D).

Among myeloid cells, neutrophils were most prevalent, with these cells being $\sim 4$-fold more numerous in ischemic hemispheres of FVB than in C57Bl6 mice (Figure 4A). There was a similar profile of both macrophage and Ly6 $6 \mathrm{C}^{\text {low }}$ monocyte numbers in the ischemic brain following stroke, with also $\sim 4$-fold more of these cells in FVB than $\mathrm{C} 57 \mathrm{Bl} / 6$ mice (Figures $4 \mathrm{~B}, \mathrm{C}$ ). Ly6 $\mathrm{C}^{\text {high }}$ monocytes and total monocytes were present in similar numbers in the ischemic brains of the two strains (Figures 4D,E). In contrast, the number of dendritic cells in the ischemic hemisphere was $\sim 3$-fold higher in $\mathrm{C} 57 \mathrm{Bl} / 6$ than FVB mice (Figure 4F).

Among lymphoid cells, there were marked increases in numbers of both $\mathrm{B}$ cells and $\mathrm{T}$ cells in the post-ischemic brain of C57Bl/6 mice but not FVB mice (Figures 5A,B). Further analysis of $\mathrm{T}$ cell subpopulations indicated that the increase in $\mathrm{C} 57 \mathrm{Bl} / 6$ mice was mostly due to infiltration of $\mathrm{CD} 4{ }^{+} \mathrm{CD} 25^{-}$("T helper") cells and not to $\mathrm{CD}^{+}$("cytotoxic") nor $\mathrm{CD} 4^{+} \mathrm{CD} 25^{+} \mathrm{T}$ cells, which includes Tregs (Figures 5C-E).

Overall, despite similar compositions of immune cells in the brains of $\mathrm{C} 57 \mathrm{Bl} / 6$ and FVB mice following sham surgery, there were marked differences between strains after stroke with lymphoid:myeloid cells representing $\sim 80: 20$ in total (Figure 6). While a similar ratio persisted in $\mathrm{C} 57 \mathrm{Bl} / 6$ mice after ischemia, there was a markedly different leukocyte composition in FVB mice after stroke, with a reversal of the lymphoid:myeloid ratio to $\sim 20: 80$ (Figure 6). There were few differences in blood composition of leukocytes between strains or after stroke (Figure 7).

\section{SPLENIC LEUKOCYTE NUMBERS}

At $24 \mathrm{~h}$ after stroke there was a tendency for a reduction in the total number of splenic leukocytes in both mouse strains (Figure 8A). There were fewer splenic myeloid cells in FVB vs. $\mathrm{C} 57 \mathrm{Bl} / 6$ mice, due to lower numbers of neutrophils and Ly6 $C^{\text {high }}$ monocytes (Figures $\mathbf{8 B}, \mathbf{D}, \mathbf{G}$ ), whereas there were higher 


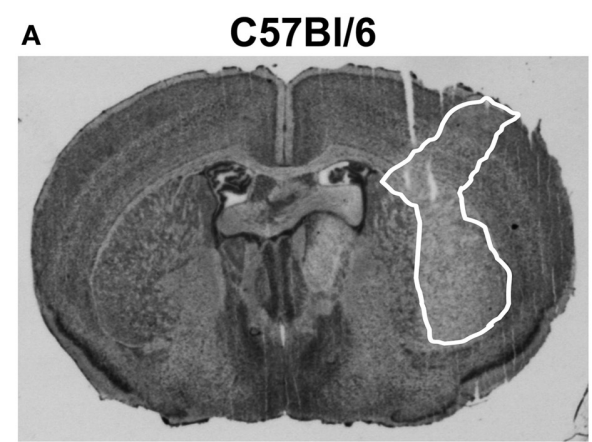

C

Total Infarct

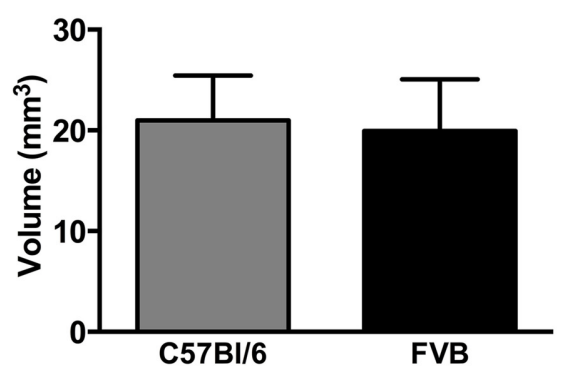

E

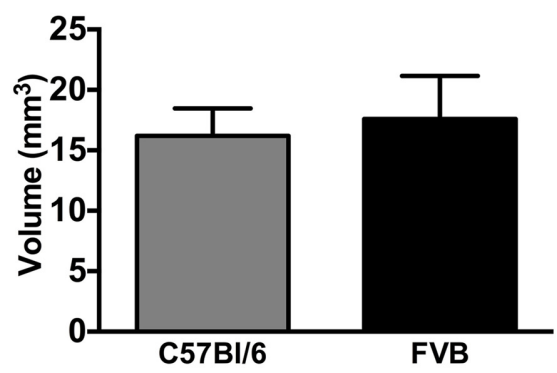

FIGURE 2 | Representative coronal brain sections from a (A) C57BI/6 mouse and a (B) FVB mouse $24 \mathrm{~h}$ after $1 \mathrm{~h}$ middle cerebral artery occlusion (infarct areas are outlined in white). Infarct [(C), total; (D),

\section{B $\quad$ FVB}

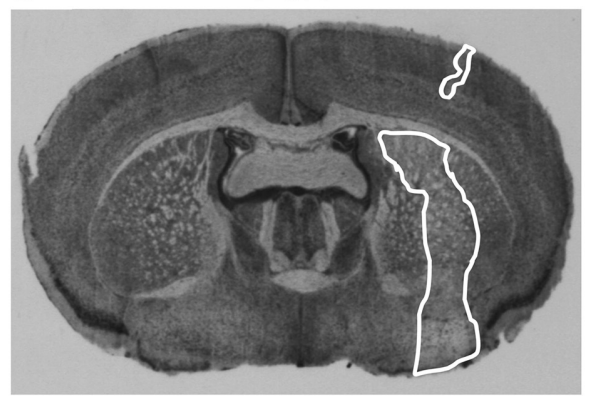

D

\section{Cortical Infarct}

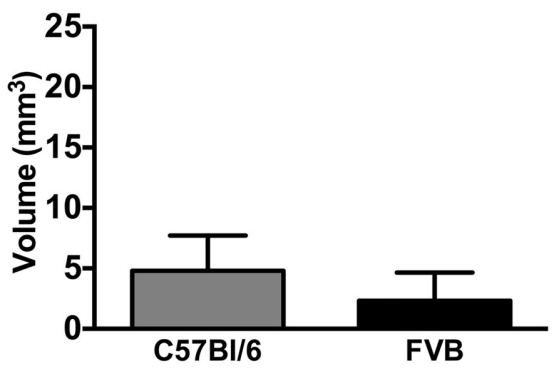

$\mathbf{F}$

Edema

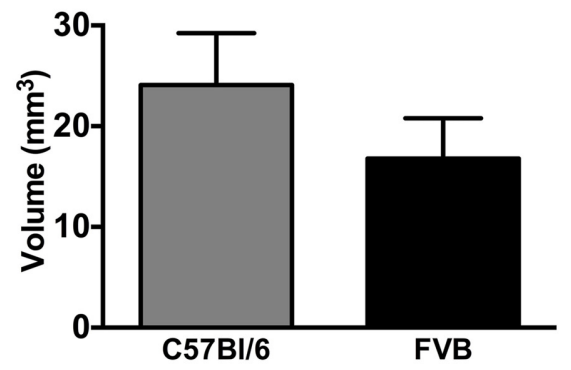

cortical; (E), subcortical] and (F) edema volumes are also shown ( $n=11$ per group; Student's unpaired $t$-test). There was no difference in the infarct volume between two strains of mice. Data are mean \pm s.e.m. numbers of $\mathrm{CD}^{+}, \mathrm{CD}^{+}$, and total $\mathrm{T}$ cells in that strain (Figures 8J-L). There was no significant reduction in any cell population (Figures 8C,E,F,H,I) except for 40-50\% fewer T cells in FVB mice (Figures 8J-L). Consistent with these data, spleen weight was slightly reduced at $24 \mathrm{~h}$ after stroke in both strains, with the difference reaching statistical significance in FVB mice only (Supplementary Figure 2).

\section{CYTOKINE LEVELS}

Brain cytokine analysis at $24 \mathrm{~h}$ indicated that stroke resulted in substantially higher mean levels of IL- 4 , IL- 6 , TNF- $\alpha$, IFN- $\gamma$, IL10 , and IL-17A in both $\mathrm{C} 57 \mathrm{Bl} / 6$ and FVB mice (Supplementary Figure 3 ). There was a tendency for higher levels of IL-4, IL-6, TNF- $\alpha$, and IFN- $\gamma$ in the ischemic hemisphere of FVB than of $\mathrm{C} 57 \mathrm{Bl} / 6$ (Supplementary Figure 3). There were no clear trends in cytokine levels in blood and spleen were generally similar in sham-operated mice of each strain, and there were no marked effects of stroke after $24 \mathrm{~h}$ in either strain (Supplementary Figures 4, 5).

\section{DISCUSSION}

There is growing evidence that $\mathrm{T}$ lymphocytes may influence the development of ischemic injury and functional deficit following experimental stroke (Iadecola and Anrather, 2011; Brait et al., 2012). For example, mice lacking $\mathrm{T}$ cells are reported to have smaller infarcts and improved functional outcome after focal ischemia compared to wild-type mice (Yilmaz et al., 2006; Hurn et al., 2007; Urra et al., 2009a; Kleinschnitz et al., 2013). Furthermore, there may be differential effects of $\mathrm{CD} 4^{+} \mathrm{T}$ cell subsets on stroke outcome, such as exacerbation by Th1 cells and amelioration by Th2 cells of brain infarct development and functional deficit (Xiong et al., 2011; Gu et al., 2012). There is also clinical evidence that single nucleotide polymorphisms in the genes of Th1 and Th2 cytokines, and molecules that regulate 


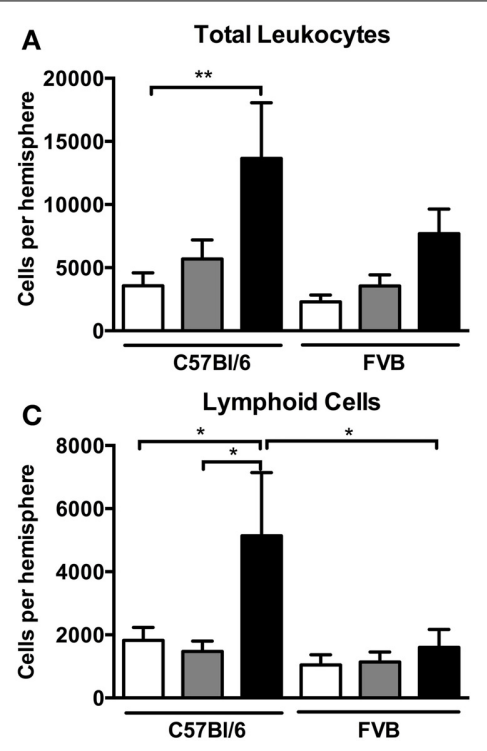

FIGURE 3 | Flow cytometric quantification of (A) total leukocytes and (B-D) leukocyte subsets in the brain at $\mathbf{2 4} \mathrm{h}$ after $\mathbf{1 ~} \mathrm{h}$ middle cerebral artery occlusion. Data are shown for the contralateral and ischemic hemispheres, and compared with sham control mice of the same strain ( $n$

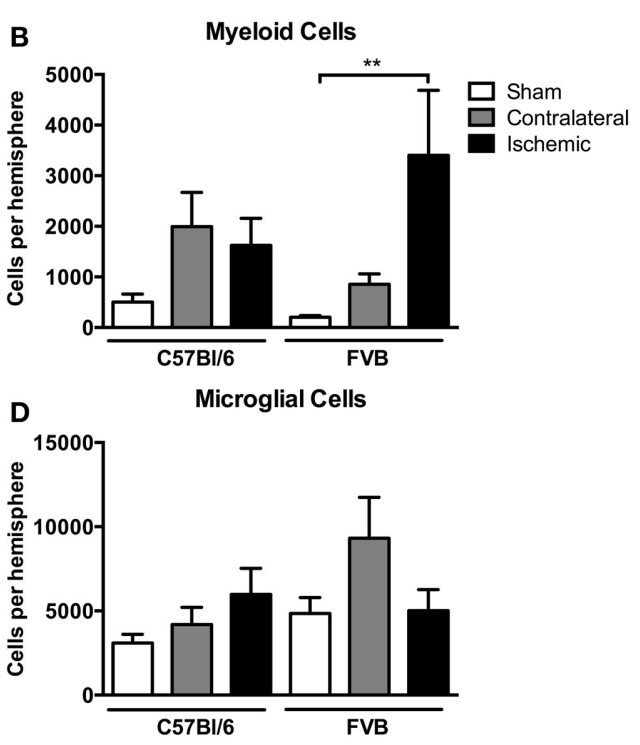

values: total leukocytes $n=13-16$, subsets $n=6-9$; $* P<0.05, * * P<0.01$; One-Way ANOVA with Bonferroni post-tests). There was a greater number of leukocytes, predominantly lymphoid cells, infiltrating the brain of $\mathrm{C} 57 \mathrm{BI} / 6$ mice compared to FVB mice. Data are mean \pm s.e.m.

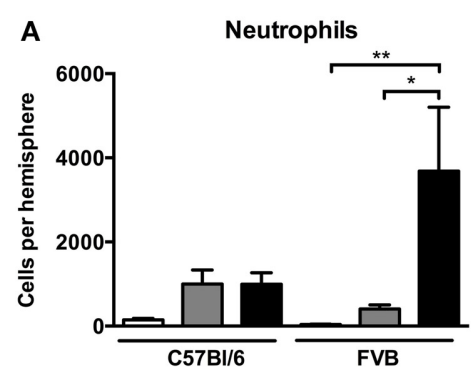

C

Ly6C Low Monocytes

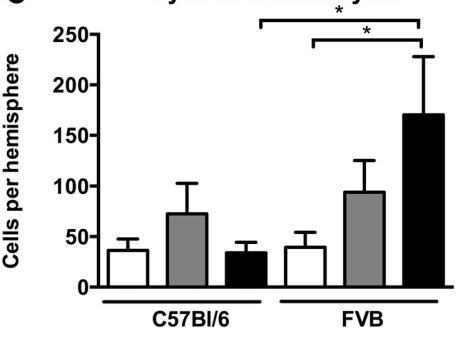

E

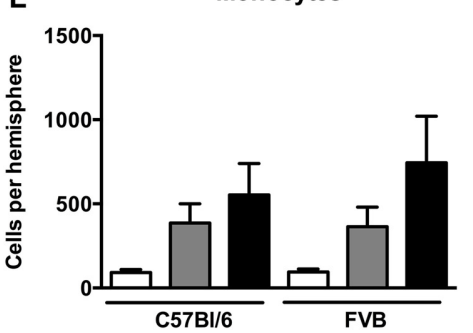

FIGURE 4 | Quantification of myeloid cell subpopulations [(A), neutrophils; (B), macrophages; (C), Ly6C low monocytes; (D), Ly6C high monocytes; (E), monocytes; (F), dendritic cells] in the brain $24 \mathrm{~h}$ after $1 \mathrm{~h}$ middle cerebral artery occlusion. Data

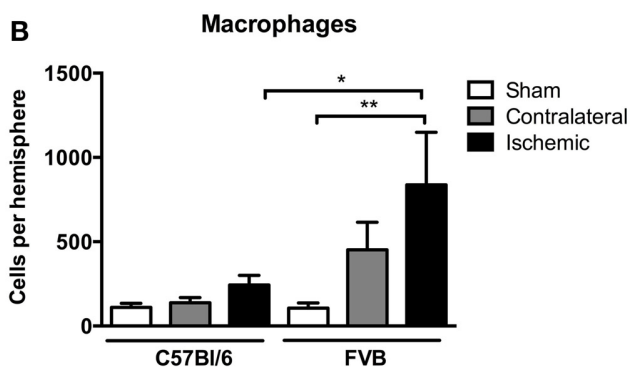

D Ly6C High Monocytes
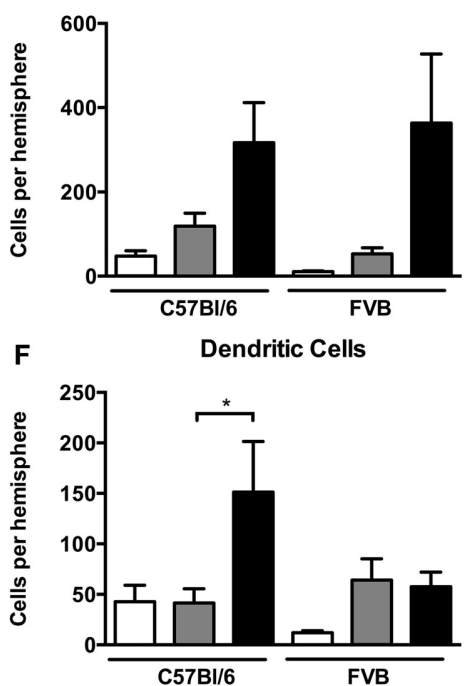

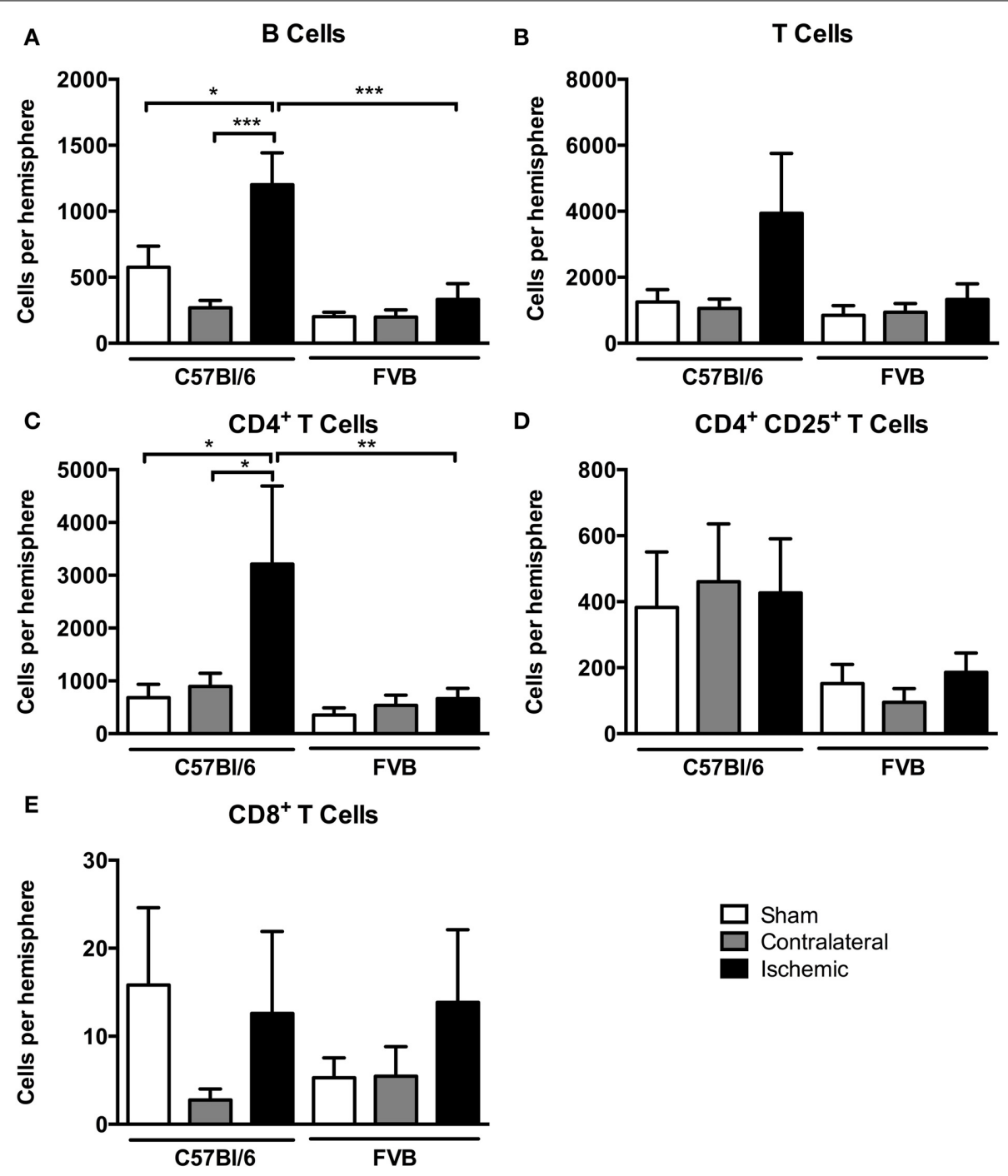

FIGURE 5 | Quantification of lymphocyte subpopulations [(A), B cells; (B), $\mathrm{T}$ cells; (C), $\mathrm{CD}^{+} \mathrm{T}$ cells; (D), CD4 ${ }^{+} \mathrm{CD}^{2} 5^{+} \mathrm{T}$ cells; (E), $\mathrm{CD}^{+} \mathrm{T}$ cells] in the brain $24 \mathrm{~h}$ after $\mathbf{1 ~} \mathrm{h}$ middle cerebral artery occlusion. Data are shown for the

their transcription rate or their functionality, may predispose to immune responses of differing strength and thus contribute to the risk of stroke (Marousi et al., 2008).

Our study has examined representative mouse strains commonly accepted as Th1-dominant (C57Bl/6) and Th2-dominant (FVB) (Whitehead et al., 2003) to investigate stroke outcome at $24 \mathrm{~h}$ in prototypical Th1- vs. Th2-prone immune environments, respectively. Our data generally support the concept that Th1prone immunity in $\mathrm{C} 57 \mathrm{Bl} / 6$ results in a more severe functional outcome after stroke compared to Th2-prone FVB mice. For example, spleen levels of IL-4 and IL-10 were 3-4-fold higher in control FVB vs. C57Bl/6 mice. Yet, with no significant differences in cerebrovascular anatomy, degree of ischemic insult caused by MCA occlusion, and ultimately in the developed infarct size between the two mouse strains, there was a markedly different profile of immune cell infiltration in the ischemic hemispheres of C57Bl/6 and FVB mice.

contralateral and ischemic hemispheres, and compared with sham control animals of the same strain $\left(n=4-8\right.$; ${ }^{*} P<0.05$, ${ }^{* *} P<0.01,{ }^{* * *} P<0.001$; One-Way ANOVA with Bonferroni post-tests). Data are mean \pm s.e.m.

Despite a similar immune cell composition in the brains of sham-operated C57Bl/6 and FVB mice, which comprised myeloid and lymphoid cells in a $\sim 20: 80$ ratio, after ischemia there was an overall increase in infiltrating cell numbers in both strains whereby this ratio was preserved in $\mathrm{C} 57 \mathrm{Bl} / 6$ but was converted to $\sim 80: 20$ in FVB mice. The magnitude of total leukocyte infiltration into the brain of $\mathrm{C} 57 \mathrm{Bl} / 6$ was approximately twice that observed in FVB, and these strain differences occurred in the absence of any notable stroke-related systemic differences such as cell numbers, cell composition or cytokine profile in either blood or spleen. Striking increases were noted to occur particularly in the number of innate immune cells such as neutrophils, macrophages and $\mathrm{LyC}^{+ \text {low }}$ monocytes infiltrating the ischemic FVB brain, whereas the most prominent increases in $\mathrm{C} 57 \mathrm{Bl} / 6$ mice occurred in the numbers of infiltrating $\mathrm{T}$ and $\mathrm{B}$ lymphocytes and dendritic cells-key cells for adaptive immunity. These responses were associated with some strain differences in the 


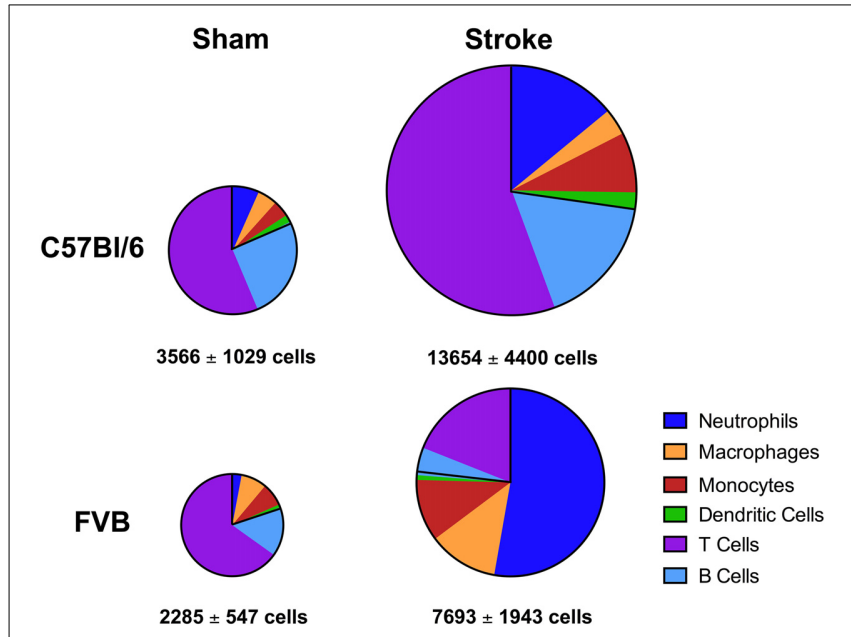

FIGURE 6 | Pie charts summarizing number and composition of immune cells in ischemic hemispheres of C57BI/6 and FVB mice at $24 \mathrm{~h}$ after $\mathbf{1 ~ h ~ m i d d l e ~ c e r e b r a l ~ a r t e r y ~ o c c l u s i o n . ~ T h e ~ a r e a ~ o f ~ e a c h ~ p i e ~ i s ~}$ proportional to the number of leukocytes per hemisphere (also shown as mean \pm s.e.m.; total leukocytes $n=13-16$, myeloid cells $n=6-9$, lymphocytes $n=4-8$ ). There was a greater number of leukocytes, predominantly lymphoid cells, infiltrating the brain of C57BI/6 mice compared to FVB mice.

mean levels of certain cytokines in the ischemic hemisphere, such as a tendency for larger amounts of both Th1 (IFN- $\gamma$, TNF- $\alpha$ ) and Th2 (IL-4, IL-6) cytokines to be present in FVB than C57Bl/6 mice. However, it is not possible from the present data to discern whether these differences in brain cytokine levels may have been a cause or effect of the different post-ischemic immune cell profiles.

We found marked differences in neutrophil content of ischemic brains between $\mathrm{FVB}$ and $\mathrm{C} 57 \mathrm{Bl} / 6$ mice. Clinical and experimental data suggest that neutrophils are the most abundant cell type in the brain after ischemia (Akopov et al., 1996; Gelderblom et al., 2009; Chu et al., 2014) and their accumulation is correlated with the severity of brain infarct and neurological deficit (Akopov et al., 1996). Activated neutrophils have been shown to promote the release of free radicals and cytokines, which further recruit leukocytes to the damaged area (Harris et al., 2005). However, it is controversial whether neutrophils contribute directly to secondary brain damage or have a mild neuroprotective role in cerebral ischemia. Animal studies have shown that increased infarct size is associated with neutrophil elimination (Takizawa et al., 2002) whilst others have shown that neutrophils may not contribute directly to infarct size (Beray-Berthat et al., 2003; Harris et al., 2005; Brait et al., 2011). Our data in FVB mice suggest that neutrophil number is not directly associated with infarct size in that a $\sim 100$-fold increase in brain infiltration after ischemia did not result in a bigger infarct size than in $\mathrm{C} 57 \mathrm{Bl} / 6$ mice where the increase was markedly less. In previous study of parasite infection, neutrophils were found to play an early role in the induction of the Th2 response that develops in Th2-prone Balb/C mice but not in $\mathrm{C} 57 \mathrm{Bl} / 6$ mice (TacchiniCottier et al., 2000). Thus, it is possible that the infiltration of neutrophils into the ischemic brains of FVB mice was associated with the induction of a less severe Th2-type immune response.

There were also markedly greater numbers of macrophages and Ly6 $6 \mathrm{C}^{\text {low }}$ monocytes (the latter are considered to be antiinflammatory) present in the FVB brains after cerebral ischemia. Macrophages and monocytes produce inflammatory cytokines and upregulate adhesion molecules in endothelial cells, thereby promoting neutrophil accumulation and migration (Chiba and Umegaki, 2013). Analogous to Th cells, macrophages are highly plastic cells and can polarize into two distinct activated macrophage subsets depending on the microenvironment (Kigerl et al., 2009). The classic or M1 activated cells are characterized by their capacity to present antigen, high production of nitric oxide and reactive oxygen species and of pro-inflammatory cytokines. In contrast, alternative or M2 activated cells are involved in scavenging of debris, angiogenesis, tissue remodeling and repair (Kigerl et al., 2009). Macrophages from Th1 strains (e.g., C57Bl/6, $\mathrm{B} 10 \mathrm{D} 2$ ) are known to be more readily activated (e.g., to produce nitric oxide) than macrophages from Th2 strains (e.g., Balb/C, DBA/2) (Mills et al., 2000). Ly6C ${ }^{\text {low }}$ monocytes are known to exhibit M2 characteristics (Geissmann et al., 2010). At the early stages following ischemic stroke, resident microglia and newly recruited macrophages appear to have a M2 phenotype that gradually transforms into an M1 phenotype in peri-infarct regions (Hu et al., 2012). It is possible that the greater number of macrophages and $\mathrm{Ly} 6 \mathrm{C}^{+ \text {low }}$ monocytes in FVB mice at $24 \mathrm{~h}$ after stroke represents more numerous M2-like cells contributing to a milder inflammatory environment in that strain. Further insight into the polarity of macrophages in FVB mice is needed.

We observed an increase in dendritic cells in the ischemic brain of $\mathrm{C} 57 \mathrm{Bl} / 6$ mice at $24 \mathrm{~h}$. Dendritic cells are involved in antigen presentation during immune cell activation and in the maintenance of peripheral tolerance through modulation of the immune response (Thompson and Thomas, 2002), but their role in outcome after cerebral ischemia is currently unclear.

There was a marked infiltration of lymphoid cells, particularly $\mathrm{B}$ and $\mathrm{CD}^{+} \mathrm{T}$ cells (i.e., Th cells), into the ischemic hemisphere of $\mathrm{C} 57 \mathrm{Bl} / 6$ mice. T lymphocytes enter the brain by $24 \mathrm{~h}$ after ischemic stroke (Gelderblom et al., 2009; Kleinschnitz et al., 2013; Chu et al., 2014), and both $\mathrm{CD}^{+}$and $\mathrm{CD}^{+}{ }^{+} \mathrm{T}$ cells contribute to post-ischemic injury in mice (Arumugam et al., 2005; Kleinschnitz et al., 2013). It is conceivable that the infiltration of $\mathrm{CD}^{+}{ }^{+}$cells, which occurred selectively in $\mathrm{C} 57 \mathrm{Bl} / 6$ mice following stroke, contributed to a more severe level of brain inflammation than in FVB mice despite a similar infarct volume. Tregs are a subset of $\mathrm{CD}^{+} \mathrm{T}$ cells that are reported to play a protective, immunomodulatory role in the brain over several days after stroke (Liesz et al., 2009), but a detrimental role during more acute conditions (Kleinschnitz et al., 2013). We found no significant changes after stroke in either $\mathrm{CD}^{+}$cells or $\mathrm{CD} 4{ }^{+} \mathrm{CD} 25^{+} \mathrm{T}$ cells, which will largely consist of Tregs.

Effects of B cells on stroke outcome are poorly understood. $B$ cells can function as antigen-presenting cells to activate cytotoxic $\mathrm{CD}^{+} \mathrm{T}$ cells, but there is also data to suggest that an IL-10-producing subpopulation of regulatory B cells may limit injury in experimental stroke (Ren et al., 2011; Bodhankar 

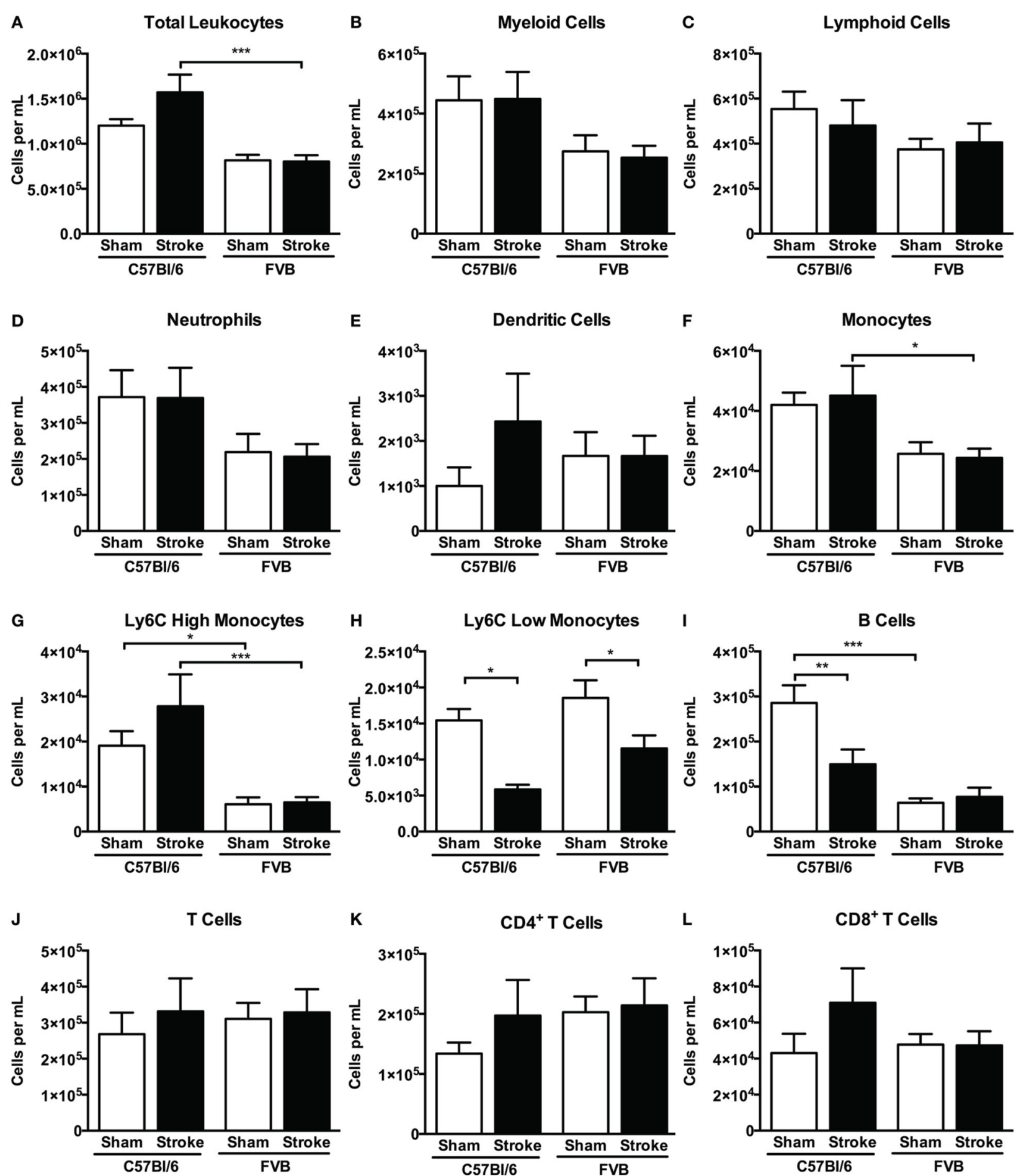

FIGURE 7 | Quantification of (A) total leukocytes and (B-L) leukocyte subsets in blood $24 \mathrm{~h}$ after $1 \mathrm{~h}$ middle cerebral artery occlusion, compared with sham control animals of the same strain (total leukocytes $n=16-28$, myeloid cells $n=9-17$, lymphocytes $n=7-12$; ${ }^{*} P<0.05,{ }^{* *} P<0.01,{ }^{* * *} P<0.001$; One-Way ANOVA with Bonferroni post-tests). Data are mean \pm s.e.m. et al., 2013). In addition, poor outcome in stroke patients is associated with reduced levels of circulating B cells (Urra et al., 2009b). Interestingly, we found that B cell infiltration into the brain following ischemia occurred selectively in $\mathrm{C} 57 \mathrm{Bl} / 6$ mice
(Figure 5A). Furthermore, whereas the number of circulating $B$ cells was $\sim 5$-fold higher in control $\mathrm{C} 57 \mathrm{Bl} / 6$ vs. FVB mice, stroke selectively reduced the number of $\mathrm{B}$ cells in the blood of the former strain (Figure 7I). Further study is necessary to clarify 
A

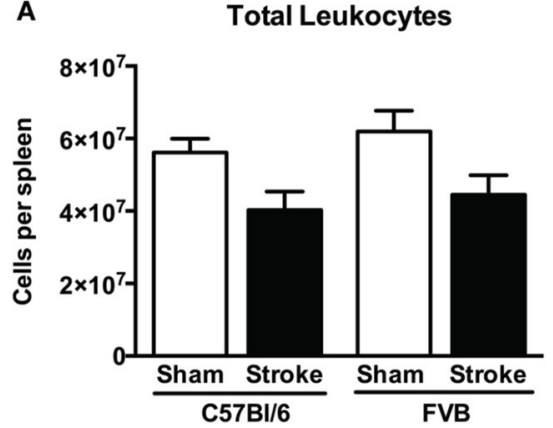

D

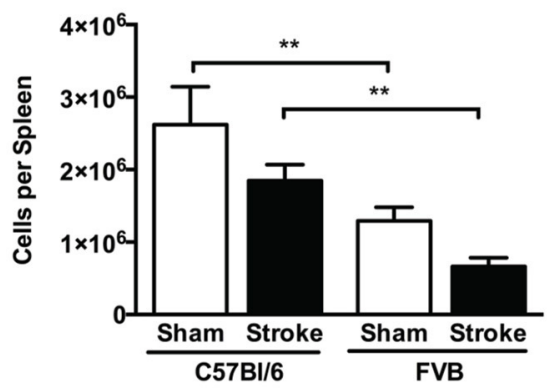

G

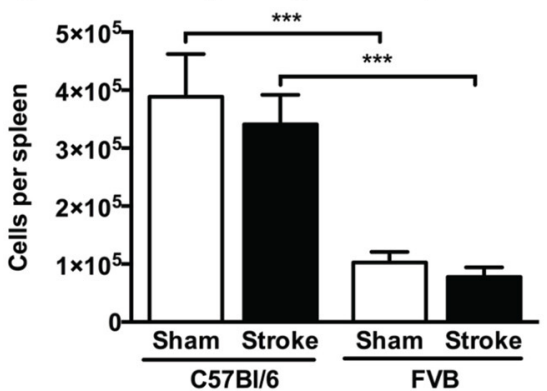

J

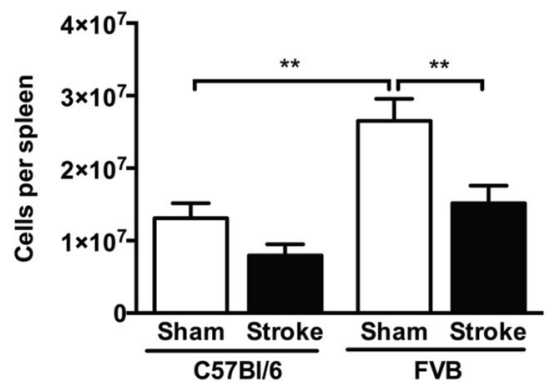

B

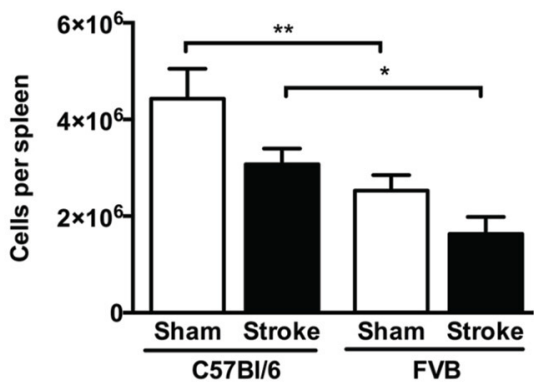

E

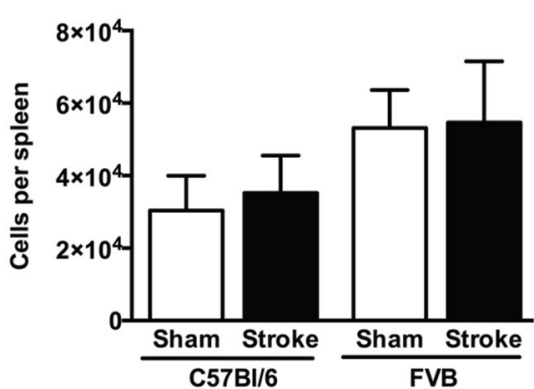

Ly6C Low Monocytes

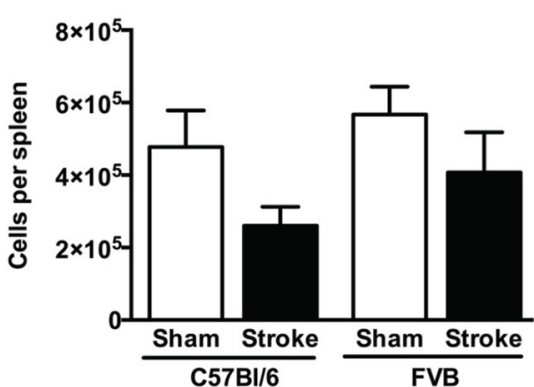

$\mathbf{K}$

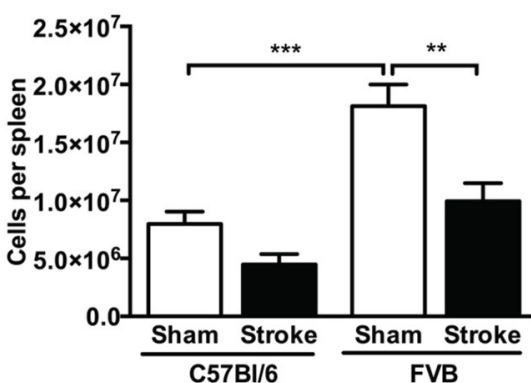

C

Lymphoid Cells

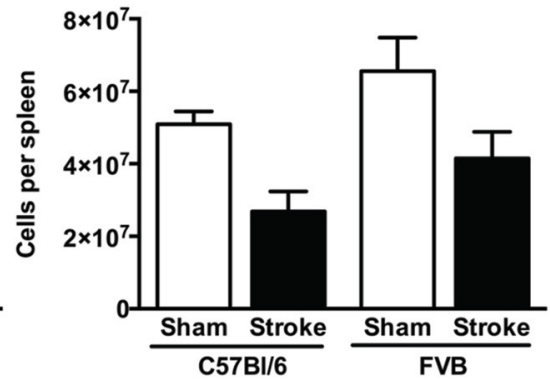

$\mathbf{F}$

Monocytes

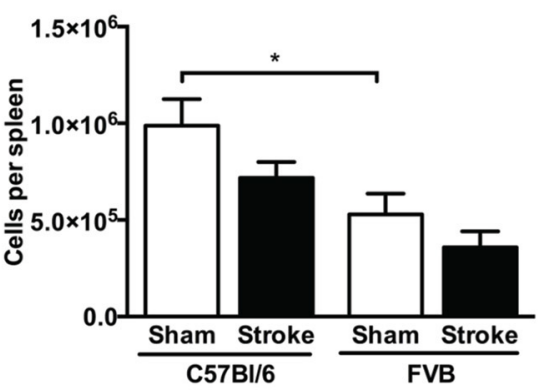

B Cells

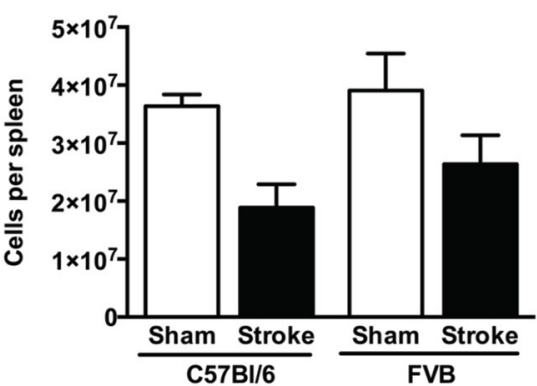

$\mathbf{L}$

CD8 ${ }^{+}$T Cells

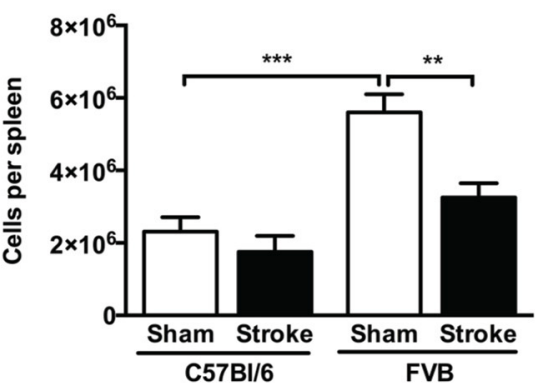

FIGURE 8 | Quantification of (A) total leukocytes and (B-L) leukocyte subsets in spleen $24 \mathrm{~h}$ after $1 \mathrm{~h}$ middle cerebral artery occlusion, compared with sham control animals of the same strain (total leukocytes $n=17-29$, myeloid cells $n=9-17$, lymphocytes $n=6-12$; ${ }^{*} P<0.05,{ }^{* *} P<0.01,{ }^{* * *} P<0.001$; One-Way ANOVA with Bonferroni post-tests). Data are mean \pm s.e.m. the importance of these strain differences in B cell number and distribution for stroke outcome.

In summary, we observed a profound difference in poststroke functional outcome which was associated with a markedly contrasting number and composition of cells infiltrating the injured brain, despite similar systemic immune cell and cytokine profiles between the two mouse strains. The data therefore suggest that the nature of the inflammatory response to brain ischemia 
can vary considerably, and it may consequently impact the functional outcome independently of the volume of injured tissue. It would appear that the early infiltration into the ischemic brain tissue of certain innate/myeloid cell types, such as neutrophils, macrophages and Ly6 $\mathrm{C}^{+ \text {low }}$ monocytes, rather than cells of the adaptive immune system, such as B and $\mathrm{T}$ lymphocytes, may assist in achieving a milder level of functional deficit.

We acknowledge that while differences in biological responses between mouse strains that possess varying genetic and immunological profiles may provide a useful tool to gain some mechanistic insight into immune cell-mediated ischemic brain injury, studies of mice of the same genetic background are needed to provide definitive conclusions regarding these complex mechanisms. Moreover, if such findings are relevant for developing effective therapies for stroke patients, it will be interesting to determine whether individuals predisposed to Th2-prone immunity, including conditions such as asthma and allergy, might experience milder brain inflammation and functional deficit after stroke.

\section{ACKNOWLEDGMENT}

These studies were supported by Project Grants from the National Health and Medical Research Council of Australia (NHMRC) (ID 1010984 and 1064686). We also acknowledge support from an Australian Research Council Future Fellowship (TVA) and NHMRC Senior Research Fellowships (GRD and CGS).

\section{SUPPLEMENTARY MATERIAL}

The Supplementary Material for this article can be found online at: http://www.frontiersin.org/journal/10.3389/fncel. 2014.00365/abstract

\section{REFERENCES}

Abbas, A. K., Murphy, K. M., and Sher, A. (1996). Functional diversity of helper T lymphocytes. Nature 383, 787-793. doi: 10.1038/383787a0

Akopov, S. E., Simonian, N. A., and Grigorian, G. S. (1996). Dynamics of polymorphonuclear leukocyte accumulation in acute cerebral infarction and their correlation with brain tissue damage. Stroke 27, 1739-1743. doi: 10.1161/01.STR.27.10.1739

Arumugam, T., Granger, D. N., and Mattson, M. (2005). Stroke and T-cells. Neuromolecular Med. 7, 229-242. doi: 10.1385/NMM:7:3:229

Beray-Berthat, V., Palmier, B., Plotkine, M., and Margaill, I. (2003). Neutrophils do not contribute to infarction, oxidative stress, and NO synthase activity in severe brain ischemia. Exp. Neurol. 182, 446-454. doi: 10.1016/S0014-4886(03) 00106-7

Bodhankar, S., Chen, Y., Vandenbark, A., Murphy, S., and Offner, H. (2013). IL-10-producing B-cells limit CNS inflammation and infarct volume in experimental stroke. Metab. Brain Dis. 28, 375-386. doi: 10.1007/s11011-0139413-3

Brait, V. H., Arumugam, T. V., Drummond, G. R., and Sobey, C. G. (2012). Importance of $\mathrm{T}$ lymphocytes in brain injury, immunodeficiency, and recovery after cerebral ischemia. J. Cereb. Blood Flow Metab. 32, 598-611. doi: $10.1038 /$ jcbfm.2012.6

Brait, V. H., Rivera, J., Broughton, B. R. S., Lee, S., Drummond, G. R., and Sobey, C. G. (2011). Chemokine-related gene expression in the brain following ischemic stroke: no role for CXCR2 in outcome. Brain Res. 1372, 169-179. doi: 10.1016/j.brainres.2010.11.087

Brait, V., Jackman, K., Walduck, A., Selemidis, S., Diep, H., Mast, A., et al. (2010). Mechanisms contributing to cerebral infarct size after stroke: gender, reperfusion, T lymphocytes, and Nox2-derived superoxide. J. Cereb. Blood Flow Metab. 30, 1306-1307. doi: $10.1038 / \mathrm{jcbfm} .2010 .14$

Chiba, T., and Umegaki, K. (2013). Pivotal Roles of Monocytes/Macrophages in Stroke. Mediators Inflamm. 2013, 10. doi: 10.1155/2013/759103
Chu, H. X., Kim, H. A., Lee, S., Moore, J. P., Chan, C. T., Vinh, A., et al. (2014). Immune cell infiltration in malignant middle cerebral artery infarction: comparison with transient cerebral ischemia. J. Cereb. Blood Flow Metab. 34, 450-459. doi: 10.1038/jcbfm.2013.217

Geissmann, F., Manz, M., Jung, S., Sieweke, M., Merad, M., and Ley, K. (2010). Development of monocytes, macrophages, and dendritic cells. Science 327, 656-661. doi: 10.1126/science.1178331

Gelderblom, M., Leypoldt, F., Steinbach, K., Behrens, D., Choe, C.-U., Siler, D. A., et al. (2009). Temporal and spatial dynamics of cerebral immune cell accumulation in stroke. Stroke 40, 1849-1857. doi: 10.1161/STROKEAHA.108.534503

Go, A. S., Mozaffarian, D., Roger, V. L., Benjamin, E. J., Berry, J. D., Blaha, M. J., et al. (2013). Heart disease and stroke statistics-2014 update: a report from the American Heart Association. Circulation 129, e28-e292. doi: 10.1161/CIR.0b013e31828124ad

Gravanis, I., and Tsirka, S. (2008). Tissue-type plasminogen activator as a therapeutic target in stroke. Expert Opin. Ther. Targets 12, 59-70. doi: 10.1517/14728222. 12.2.159

Gu, L., Xiong, X., Zhang, H., Xu, B., Steinberg, G. K., and Zhao, H. (2012). Distinctive effects of $\mathrm{T}$ cell subsets in neuronal injury induced by cocultured splenocytes in vitro and by in vivo stroke in mice. Stroke 43, 1941-1946. doi: 10.1161/STROKEAHA.112.656611

Harris, A., Ergul, A., Kozak, A., Machado, L., Johnson, M., and Fagan, S. (2005). Effect of neutrophil depletion on gelatinase expression, edema formation and hemorrhagic transformation after focal ischemic stroke. BMC Neurosci. 6:49. doi: 10.1186/1471-2202-6-49

Hu, X., Li, P., Guo, Y., Wang, H., Leak, R. K., Chen, S., et al. (2012). Microglia/macrophage polarization dynamics reveal novel mechanism of injury expansion after focal cerebral ischemia. Stroke 43, 3063-3070. doi: 10.1161/ STROKEAHA.112.659656

Hurn, P. D., Subramanian, S., Parker, S. M., Afentoulis, M. E., Kaler, L. J., Vandenbark, A. A., et al. (2007). T- and B-cell-deficient mice with experimental stroke have reduced lesion size and inflammation. J. Cereb. Blood Flow Metab. 27, 1798-1805. doi: 10.1038/sj.jcbfm.9600482

Iadecola, C., and Anrather, J. (2011). The immunology of stroke: from mechanisms to translation. Nat. Med. 17, 796-808. doi: 10.1038/nm.2399

Jackman, K., Miller, A., De Silva, T., Crack, P., Drummond, G., and Sobey, C. (2009). Reduction of cerebral infarct volume by apocynin requires pretreatment and is absent in Nox2-deficient mice. Br. J. Pharmacol. 156, 680-688. doi: 10.1111/j.1476-5381.2008.00073.x

Jin, R., Yang, G., and Li, G. (2010). Inflammatory mechanisms in ischemic stroke: role of inflammatory cells. J. Leukoc. Biol. 87, 779-789. doi: 10.1189/jlb. 1109766

Kigerl, K. A., Gensel, J. C., Ankeny, D. P., Alexander, J. K., Donnelly, D. J., and Popovich, P. G. (2009). Identification of two distinct macrophage subsets with divergent effects causing either neurotoxicity or regeneration in the injured mouse spinal cord. J. Neurosci. 29, 13435-13444. doi: 10.1523/JNEUROSCI.3257-09.2009

Kilkenny, C., Browne, W., Cuthill, I. C., Emerson, M., and Altman, D. G. (2010). Animal research: reporting in vivo experiments: the ARRIVE guidelines. J. Gene. Med. 12, 561-563. doi: 10.1002/jgm.1473

Kim, H. A., Brait, V. H., Lee, S., De Silva, T. M., Diep, H., Eisenhardt, A., et al (2012). Brain infarct volume after permanent focal ischemia is not dependent on Nox2 expression. Brain Res. 1483, 105-111. doi: 10.1016/j.brainres.2012. 09.023

Kleinschnitz, C., Kraft, P., Dreykluft, A., Hagedorn, I., Göbel, K., Schuhmann, M. K., et al. (2013). Regulatory T cells are strong promoters of acute ischemic stroke in mice by inducing dysfunction of the cerebral microvasculature. Blood 121, 679-691. doi: 10.1182/blood-2012-04-426734

Kleinschnitz, C., Schwab, N., Kraft, P., Hagedorn, I., Dreykluft, A., Schwarz, T., et al. (2010). Early detrimental T-cell effects in experimental cerebral ischemia are neither related to adaptive immunity nor thrombus formation. Blood 115, 3835-3842. doi: 10.1182/blood-2009-10-249078

Liesz, A., Suri-Payer, E., Veltkamp, C., Doerr, H., Sommer, C., Rivest, S., et al. (2009). Regulatory $\mathrm{T}$ cells are key cerebroprotective immunomodulators in acute experimental stroke. Nat. Med. 15, 192-199. doi: 10.1038/ nm.1927

Marousi, S., Ellul, J., and Karakantza, M. (2008). Genetic polymorphisms of Type1 and Type-2 inflammatory cytokines in ischaemic stroke. Vasc. Dis. Prev. 5, 89-103. doi: 10.2174/156727008784223981 
Mills, C. D., Kincaid, K., Alt, J. M., Heilman, M. J., and Hill, A. M. (2000). M-1/M2 macrophages and the Th1/Th2 paradigm. J. Immunol. 164, 6166-6173. doi: 10.4049/jimmunol.164.12.6166

Ren, X., Akiyoshi, K., Dziennis, S., Vandenbark, A., Herson, P., Hurn, P., et al. (2011). Regulatory B cells limit CNS inflammation and neurologic deficits in murine experimental stroke. J. Neurosci. 8, 8556-8563. doi: 10.1523/JNEUROSCI.1623-11.2011

Tacchini-Cottier, F., Zweifel, C., Belkaid, Y., Mukankundiye, C., Vasei, M., Launois, P., et al. (2000). An immunomodulatory function for neutrophils during the induction of a $\mathrm{CD}^{+}$Th2 response in $\mathrm{BALB} / \mathrm{c}$ mice infected with Leishmania major. J. Immunol. 165, 2628-2636. doi: 10.4049/jimmunol.165. 5.2628

Takizawa, S., Aratani, Y., Fukuyama, N., Maeda, N., Hirabayashi, H., Koyama, H., et al. (2002). Deficiency of myeloperoxidase increases infarct volume and nitrotyrosine formation in mouse brain. J. Cereb. Blood Flow Metab. 22, 50-54. doi: 10.1097/00004647-200201000-00006

Thompson, A. G., and Thomas, R. (2002). Induction of immune tolerance by dendritic cells: implications for preventative and therapeutic immunotherapy of autoimmune disease. Immunol. Cell Biol. 80, 509-519. doi: 10.1046/j.14401711.2002.01114.x

Tsuchiya, D., Hong, S., Kayama, T., Panter, S. S., and Weinstein, P. R. (2003). Effect of suture size and carotid clip application upon blood flow and infarct volume after permanent and temporary middle cerebral artery occlusion in mice. Brain Res. 970, 131-139. doi: 10.1016/S0006-8993(03)02300-X

Urra, X., Cervera, A., Villamor, N., Planas, A. M., and Chamorro, A. (2009a). Harms and benefits of lymphocyte subpopulations in patients with acute stroke. Neuroscience 158, 1174-1183. doi: 10.1016/j.neuroscience.2008. 06.014

Urra, X., Villamor, N., Amaro, S., Gomez-Choco, M., Obach, V., Oleaga, L., et al. (2009b). Monocyte subtypes predict clinical course and prognosis in human stroke. J. Cereb. Blood Flow Metab. 29, 994-1002. doi: 10.1038/jcbfm. 2009.25
Whitehead, G. S., Walker, J. K. L., Berman, K. G., Foster, W. M., and Schwartz, D. A. (2003). Allergen-induced airway disease is mouse strain dependent. Am. J. Physiol. Lung Cell. Mol. Physiol. 285, L32-L42. doi: 10.1152/ajplung.00390.2002

Xia, C.-F., Smith, R. S., Shen, B., Yang, Z.-R., Borlongan, C. V., Chao, L., et al. (2006). Postischemic brain injury is exacerbated in mice lacking the kinin B2 receptor. Hypertension 47, 752-761. doi: 10.1161/01.HYP.0000214867.35632.0e

Xiong, X., Barreto, G. E., Xu, L., Ouyang, Y. B., Xie, X., and Giffard, R. G. (2011). Increased brain injury and worsened neurological outcome in interleukin-4 knockout mice after transient focal cerebral ischemia. Stroke 42, 2026-2032. doi: 10.1161/STROKEAHA.110.593772

Yilmaz, G., Arumugam, T. V., Stokes, K. Y., and Granger, D. N. (2006). Role of T lymphocytes and interferon- $\gamma$ in ischemic stroke. Circulation 113, 2105-2112. doi: 10.1161/CIRCULATIONAHA.105.593046

Conflict of Interest Statement: The authors declare that the research was conducted in the absence of any commercial or financial relationships that could be construed as a potential conflict of interest.

Received: 12 September 2014; paper pending published: 01 October 2014; accepted: 16 October 2014; published online: 19 November 2014.

Citation: Kim HA, Whittle SC, Lee S, Chu HX, Zhang SR, Wei Z, Arumugam TV, Vinh A, Drummond GR and Sobey CG (2014) Brain immune cell composition and functional outcome after cerebral ischemia: comparison of two mouse strains. Front. Cell. Neurosci. 8:365. doi: 10.3389/fncel.2014.00365

This article was submitted to the journal Frontiers in Cellular Neuroscience.

Copyright (c) 2014 Kim, Whittle, Lee, Chu, Zhang, Wei, Arumugam, Vinh, Drummond and Sobey. This is an open-access article distributed under the terms of the Creative Commons Attribution License (CC BY). The use, distribution or reproduction in other forums is permitted, provided the original author(s) or licensor are credited and that the original publication in this journal is cited, in accordance with accepted academic practice. No use, distribution or reproduction is permitted which does not comply with these terms. 